\title{
The Difficult Defense of Cicero's Goodness in Institutio oratoria 12.1
}

\section{Introduction: Was Cicero a Vir Bonus?}

Midway through Institutio 12.1, Quintilian confronts a problem that threatens to wreck his enterprise of educating "the good man skilled in speaking" (12.1.1, vir bonus dicendi peritus). ${ }^{1}$ How can Cicero, whom Quintilian has treated as the font of oratorical wisdom and Roman oratory's most outstanding exponent, calling him "the name not of a man but of eloquence itself" $(10.1 .112),{ }^{2}$ be considered an orator under Quintilian's definition if Cicero was not a vir bonus? Read quickly, Quintilian's judgment seems equivocal. ${ }^{3}$ He praises Cicero's meritorious conduct but concedes that he may lack "consummate virtue" (12.1.18: summa virtus). He claims that Cicero occupies the "peak" (fastigium) of eloquence but admits that his oratorical exuberance could have used even more tempering (12.1.20). Quintilian's final judgment, that Cicero can be called a perfect orator in a casual sense but that he ultimately fell short of perfect excellence (12.1.19-20), seems to subordinate his enthusiasm for Cicero to the purity of the ideal orator he is seeking. ${ }^{4}$ Upon closer examination, however, this passage proves to be a rich locus for exploring Quintilian's wider commitments and observing how he maintains balance when these seem to conflict with one another. ${ }^{5}$ Quintilian performs this balancing act in 12.1 as a rhetorical exercise that pays homage to Cicero while demonstrating a key lesson of Book 12: how to plead a difficult case

1 Quintilian credits Cato the Elder with this definition, as does Seneca the Elder in the prologue to his Controversiae (1.9). Cf. also Cic. de orat. 2.85: Tantum ego in excellenti oratore, et eodem viro bono, pono esse ornamenti universae civitati. Latin text is from Wilkins' 1892 edition of De Oratore.

2 See La Bua 2019, 3; 100 and Gowing 2013, 249.

3 For instance, Austin 1948 remarks in his note on Quint. 12.1.14: "Q. hedges uncomfortably". 4 Likewise, Cicero says that the consummate orator he is seeking is not identifiable with any particular individual but is primarily an ideal (Cic. orat.7). Layers of Ciceronian false modesty may of course be present (cf. Cic. Brut. 296 and orat. 100-102), but Quintilian can and does claim he is following Ciceronian precedent in continuing the search for the perfect orator (see Quint. 12.1.19-20, discussed in section 6 below: Eum quaeram oratorem quem et ille quaerebat). 5 As Quintilian states in 3.1.22, he draws from a variety of sources without rigidly adhering to any single secta.

Ә OpenAccess. (C) 2022 Rosalie Stoner, published by De Gruyter. (cc) BY This work is licensed under the Creative Commons Attribution 4.0 International License. https://doi.org/10.1515/9783110748703-007 
while maintaining one's own moral integrity and working towards a good outcome. ${ }^{6}$

When read within the context of Institutio 12, it becomes clear that the main motivation fueling Quintilian's complex defense of Cicero is his desire to protect his moral definition of the orator from invalidation. In order to preserve the integrity of his own work, he must establish the goodness of Cicero, his main inspiration. Quintilian responds to the accusations of Cicero's detractors in order to resolve the conflict of Cicero's imperfections with his basic moral goodness and thus confirm his usefulness for Quintilian's educational project. He does this by admitting select weaknesses while insisting on Cicero's fundamental goodness, which is supported, of course, by his outstanding eloquence. ${ }^{7}$

In order to show this, I first identify the specific objections to Cicero's goodness that appear to be at issue and trace how Quintilian responds to each of them. Next, I explain the structure of Institutio 12.1.14-22 as a defense that features Quintilian as Cicero's advocate, mustering proof and conciliating his audience in the service of his cause. I then situate the passage within Book 12 as part of a larger argument supporting Quintilian's ideal of the orator as a vir bonus dicendi peritus. I argue that this passage serves as a "teaching example" of how to go about the difficult defense that the vir bonus may have to undertake in the service of his client or of the common good. ${ }^{8}$ Finally, I locate Cicero within Quintilian's expansion of the Ciceronian quest for the perfect orator through a reading of the prologue of Institutio 12.

\section{Quintilian's Defense I: Cicero's Good Intentions}

Criticisms of both Cicero's and Demosthenes' characters are mounted in 12.1.14 as part of a larger objection to the moral ideal of the orator. Quintilian refers

6 Cf. Gunderson 2009 for the Institutio as "a rhetorical performance" (109) that "exemplifies its own theory of rhetoric" (113). Dozier 2014 further develops the Institutio's "rhetorical dimension" (71) through an analysis of 12.8 .

7 La Bua notes how "Pollio and Livy, finally, judge Cicero by balancing his virtues against his vices” (110). By contrast, I think Quintilian judges Cicero by claiming that his virtue, albeit imperfect, is more fundamental to his character than are his faults.

8 Gunderson 2009, Taoka 2011, and Dozier 2014 offer parallel arguments and observations (focusing on 6. pr.; 10.1.125-131; and 12.8, respectively) about the ways in which Quintilian performs the principles he teaches in the Institutio. 
to the cluster of complaints as a conspiracy (quasi conspiratione quadam). "Was not Demosthenes then an orator? But we have learned that he was a bad man. Was not Cicero an orator? But many people have censured his character also" (atqui huius quoque mores multi reprenderunt). ${ }^{10}$

Who are the multi, and what mores do they disapprove of in Cicero? Many scholars have discussed Cicero's critics, especially those in the declamatory tradition, in the intervening century and a half between his death and Quintilian's writing. ${ }^{11}$ The pseudepigraphal invective of Sallust against Cicero and the vituperation of Asinius Pollio, partially preserved in the Elder Seneca's sixth suasoria, represent some of the most bitter attacks on Cicero, while Seneca the Younger emphasizes Cicero's moral weakness (though he praises his oratorical prowess). ${ }^{12}$ The pseudo-Sallustian invective accuses Cicero of being, among other things, fickle (5: homo levissimus); cruel and violent in his actions during the Catilinarian conspiracy (5-6); lacking in fides (7); and afflicted by a "disease of the mind" (1: morbus animi). ${ }^{13}$ Pollio complains of Cicero's lack of moderation in favorable circumstances and his lack of courage in adverse ones. ${ }^{14}$ Likewise, Seneca the Younger famously characterizes Cicero in De Brevitate Vitae as tossed about on the waves of his fortunes and misfortunes, carried away by excessive self-praise in good times and excessive despair in bad ones, unable to preserve equanimity and to be called a sapiens. ${ }^{15}$

Picking up on these earlier criticisms of Cicero, three main moral objections seem to underlie Quintilian's defense in 12.1.14-22: cowardice, inordinate boasting, and blameworthy actions undertaken in a political context. The last category is not as explicit in the passage I am examining here, but Cicero's execution of

9 I will discuss the significance of this comparison in section 6 below.

10 Quint. 12.1.14: Orator ergo Demosthenes non fuit? atqui malum virum accepimus. Non Cicero? atqui huius mores multi reprenderunt. All English translations are my own, unless otherwise noted. The Latin text of the Institutio oratoria is from Russell's 2001 Loeb, which largely reproduces Winterbottom's 1970 OCT with some emendations.

11 See Chapter 3 of La Bua 2019 (esp. 100 -112) and Chapter 4 of Keeline 2018 (esp. 147-177) for discussions of the main declamatory sources of criticism of Cicero in the early imperial period. 12 For a critical edition of the pseudo-Sallustian invective against Cicero, see Novokhatko 2009. On Asinius Pollio's criticism of Cicero see La Bua 2019, 107-110, Keeline 2018, 135-137, and Austin 1948, 63. For Seneca the Younger's moral assessment of Cicero, see Degl'Innocenti Pierini 2018, 24-29 and Gowing 2013, 239-244.

13 Fulkerson 2013 explains Cicero's supposed levitas as a consequence of his precarious political situation as a novus homo and emphasizes that Cicero at least considered himself to possess constantia in his devotion to the res publica despite fluctuating circumstances. See especially 247; 250; 253; 260 -261. On pseudo-Sallust's accusations, see also Keeline 2018, 155-158.

14 Sen. suas.6.24.

15 Sen. brev. 5.1. 
the Catilinarian conspirators and his unabashed deception of the judges in speeches like Pro Cluentio and Pro Milone ${ }^{16}$ are events that could trigger complaint, or at least cast a shadow on his character. Examining each area of criticism and Quintilian's response to it shows that Quintilian is not intransigent in defending his hero; rather, he seeks to subordinate a concession of Cicero's weaknesses to a favorable judgment of his good intentions.

Quintilian's first concern is to sketch an outline of Cicero's admirable political deeds in order to demonstrate the fundamental goodness of his personal character and public actions. Importantly, Quintilian does not say that Cicero was "the best citizen" ${ }^{17}$, but rather that he did not lack "the will of a very fine citizen" (12.1.16: civis optimi voluntatem). This allows Quintilian room to claim a basic and stable goodness for Cicero without having to prove the absolute perfection of every one of his deeds. Quintilian's account reads as follows (12.1.16-17):

Nec M. Tullio defuisse video in ulla parte civis optimi voluntatem. Testimonio est actus nobilissime consulatus, integerrime provincia administrata et repudiatus vigintiviratus, et civilibus bellis, quae in aetatem eius gravissima inciderunt, neque spe neque metu declinatus animus quo minus optimis se partibus, id est rei publicae, iungeret. Parum fortis videtur quibusdam, quibus optime respondit ipse non se timidum in suscipiendis sed in providendis periculis: quod probavit morte quoque ipsa, quam praestantissimo suscepit animo.

I do not see that Cicero in any way lacked the will of a very fine citizen. As evidence, his consulship was conducted most nobly, his province was administered with utmost integrity and he refused a place on the Land Commission, ${ }^{18}$ and in the civil wars, which fell as very weighty burdens on his time, his spirit did not swerve from joining the best party (namely, the republic) because of hope of gain or fear of loss. He seems insufficiently strong to some people, to whom he himself gave the best response: that he was timid not in accepting dangers but in foreseeing them; and he proved this fact also by his very death, which he met with outstanding strength of spirit.

The abundant superlatives in this passage contrast Cicero's virtues with the grave dangers that he faced (civis optimi, nobilissime, integerrime, gravissima, optimis partibus, optime respondit, praestantissimo animo). These strong affirmations of Cicero's nobility drown out words that suggest he was lacking in something (defuisse, parum). But what does Quintilian mean when he says that he

16 Quintilian discusses the Pro Milone in many passages; see especially 4.2.57-59 for praise of Cicero's artful deception in this speech. For deception in the Pro Cluentio see especially 2.17.21, discussed below.

17 Cf. Gowing 2013, 246.

18 See Rising 2015 for a summary of historical information and scholarly debate on Cicero's rejection of Caesar's offer of a place on the 'Board of Twenty' in 59 BC. 
thinks Cicero had "the will (voluntas) of a very fine citizen"? ${ }^{19}$ The moral defense of Cicero is laid out in terms of choices that Cicero made, choices in which he embraced and refused the proper things. Cicero knew both how to choose or accept arduous goods and how to decline attractive evils. On the one hand, he joined the noble defenders of the republic and accepted his own death in an impressive manner. On the other, he refused a place on Caesar's Campanian land commission (repudiatus vigintiviratus). His espousal of the nobler side in the civil war involved hardening his mind against the distracting lures of spes and metus. Alongside his adherence to the res publica, his resistance to spes and metus counteracts charges of levitas and mental unsteadiness. Quintilian's brief and selective biography of Cicero thus portrays him equipped with the voluntas of an exemplary citizen, embracing noble and difficult things while refusing unjust or unworthy things. He can therefore be accounted a vir bonus, even if he did not attain consummate virtue (12.1.18: quod si defuit his viris summa virtus).

It is important to note what Quintilian passes over or minimizes in this passage. For instance, he does not overtly mention Cicero's controversial actions during the Catilinarian conspiracy and its aftermath, which were subject to much criticism, ${ }^{20}$ though he elsewhere expresses his wholehearted approval of Cicero's conduct in this matter (11.1.18). ${ }^{21}$ Here, he only implies his support by saying that Cicero's consulship was conducted nobly (nobilissime). Nor does Quintilian mention Cicero's self-satisfied deception of the judges in Pro Cluentio, which he defends in 2.17.21 and will defend again, more implicitly, in 12.1.33-45 as he argues for the upright orator's prerogative to deceive the judges. ${ }^{22}$ Quintilian is playing a careful game in 12.1.14-22. While acknowledging and confronting key criticisms leveled against Cicero, he wants to make sure that Cicero ultimately appears in a favorable light. This involves being selective about what material to present, what to leave out, and which arguments to employ in order to optimize his portrayal of Cicero.

19 I think "intention" would be an equally acceptable translation for voluntas here.

20 See La Bua 2019, 107.

21 See 11.1.18, discussed in section 3 below.

22 I discuss this prerogative at greater length in section 5 below. Quint. 2.17 is trying to prove that rhetoric is truly an art and that it does not acquiesce to false opinions, which would imply that it does not have true perception, a Stoic idea (Russell 2001 ad loc.). Quintilian says that rhetoric may present false things in the guise of truth but without its practitioner being himself deceived, as Cicero employed falsehoods in defending Cluentius without himself being mistaken about the truth (Quint. 2.17.21: Nec Cicero, cum se tenebras offudisse iudicibus in causa Cluenti gloriatus est, nihil ipse vidit). 


\section{Quintilian's Defense II: Cicero's Courage and Self-Confidence}

Quintilian's response to allegations of Cicero's cowardice is a good example of this careful game. To some critics, Cicero seems lacking in strength (parum fortis) and, implicitly, fearful (timidum, 12.1.17). ${ }^{23}$ As Giuseppe La Bua has pointed out, Seneca had criticized Cicero's "psychological instability" in De Brevitate Vitae 5.1-2, arguing that no sapiens would ever call himself semiliber under constraint from external circumstances. ${ }^{24}$ Quintilian himself has devoted significant energy in 12.1 to the evils of a mala mens, whose doubts and anxieties prevent it from focusing on the arts necessary for oratorical excellence. ${ }^{25}$ As later parts of Institutio 12 demonstrate, fearfulness is incompatible with the ethos of the morally good orator, who needs to purge away cowardly sensations in order to persuade effectively (12.2.3) and keep his mind steady to engage in oratorical combat (12.5.2-4). ${ }^{26}$ In our passage, however, Quintilian emphasizes actions that show Cicero's courage, particularly his death (12.1.17, quam praestantissimo suscepit animo) to suggest that Cicero's actions were courageous at a fundamental level. ${ }^{27}$ He may have oscillated and worried ahead of time, but at the decisive moment of his assassination, he bore the ultimate terror courageously. Cicero also appears in 12.7.4 among the list of leading citizens whose prosecution of wicked men demonstrates their possession of a certain basic courage and confidence (fiducia bonae mentis). The attribution of fiducia bonae mentis to Cicero may seem at odds with Quintilian's totalizing language in 12.1.4-6 about how the mind must be completely free of vice in order to study and how virtue and

23 Russell ad loc. points out for comparison Cicero's letter to Toranius (Cic. Fam. 246/ 6.21), in which he says that Domitius and Lentulus considered him timidus for anticipating what in fact came to pass.

24 La Bua 2019, 110.

25 Quint. 12.1.7: Nihil est enim tam occupatum, tam multiforme, tot ac tam variis adfectibus concisum atque laceratum quam mala mens. Nam et cum insidiatur, spe curis labore distringitur, et, etiam cum sceleris compos fuit, sollicitudine, paenitentia, poenarum omnium expectatione torquetur. Quis inter haec litteris aut ulli bonae arti locus?

26 Some moderate anxiety is permissible and even praiseworthy, as long as it does not keep the orator from doing what must be done (Quint. 12.5.4).

27 Livy and Pollio both offer positive assessments of Cicero's courage at the moment of death (Sen. suas. 6.21-25). 
vice cannot exist together within a single person. ${ }^{28}$ But Quintilian bridges this difficulty in 12.1.19 when he distinguishes between an approximate way of speaking about goodness and a strictly true one. ${ }^{29}$ The point is to portray Cicero as basically courageous and thus to minimize and override aspects of his character, life, and writings that could serve as evidence to the contrary.

Another area of criticism that Quintilian touches on is Cicero's propensity for self-glorification. ${ }^{30}$ In our passage, Quintilian's only explicit allusion to this fault is to call Cicero minime sui contemptor, "not at all one to despise himself" (12.1.20), but in 11.1.17-28 he provides a more extensive defense of Cicero on this front that is worth comparing with 12.1. After recommending quiet consciousness of one's own strengths, Quintilian notes that many people have criticized Cicero for his excessive self-praise (11.1.17, reprehensus est in hac parte non mediocriter Cicero). As in Book 12, Quintilian lays out a standard of behavior (the vir bonus in 12, avoidance of self-praise in 11) and then feels the need to defend Cicero from charges of violating this principle. Quintilian's defense in 11.1 follows the progression of status theory. He cannot deny that Cicero praised himself abundantly, so he attempts to justify it as follows. According to Quintilian, Cicero boasted more about his political deeds than about his oratory, the latter being a more tasteless offense (11.1.18); he had to boast about his political deeds in order to defend others or himself against the invidia that drove him into exile (11.1.18, also 11.1.23); even when he did boast about his eloquence, he did not do so immoderately (11.1.19-20); at any rate, the positive things he said about his own eloquence were true (11.1.21); if this is still a fault, it is a more excusable fault than false humility (11.1.21); Cicero shared praise of his suppression of the Catilinarian conspiracy (coniuratio) with the senate and the gods and was acting in self-defense (11.1.23); ${ }^{31}$ perhaps it is true that his poetry was over the top, but people have been unnecessarily nasty about it (quae non desierunt carpere ma-

28 See Kennedy 1969, 124 for Quintilian's Stoicizing "polarization of good and bad" such that an individual cannot combine elements of both but is either "perfectly good or perfectly villainous".

29 In a similar context in De Officiis, Cicero himself had cited the Stoic Panaetius in distinguishing between a colloquial register of speech and a more precise one useful in philosophical disputation (alia est illa, cum veritas ipsa limatur in disputatione, subtilitas, alia, cum ad opinionem communem omnis accommodatur oratio. Quam ob rem, ut volgus, ita nos hoc loco loquimur, ut alios fortes, alios viros bonos, alios prudentes esse dicamus). Latin text is from Miller's 1913 Loeb edition.

30 See Dugan 2014 for a psychoanalytic reading of Cicero’s re-visitations of his own consulship. Allen 1954 argues that Cicero's "vanity" was not in fact as unusual and offensive as modern readers might be led to believe by the criticisms of his enemies.

31 Cf. Kaster 2020b. 
ligni) and sometimes he was just imitating Greek sources (11.1.24); fiducia in one's own eloquentia is good, and no one can disapprove of Cicero for demonstrating this confidence in his Philippics (11.1.25-26).

What is the purpose of this elaborate defense, and what is its relevance to our passage in 12.1? In both defenses of Cicero, Quintilian is working hard to resolve apparent contradictions that he himself has stirred up. In 11.1.16, he has called bragging (iactatio) a vice (vitiosa) and insisted that it is self-defeating because it alienates the audience, regardless of their relation to the speaker (11.1.17: invident humiliores, rident superiores, improbant boni). Almost immediately, then, he has to reconcile this principle with the fact that Cicero often acted to the contrary. In both places Quintilian concedes Cicero's weaknesses in a limited way while maintaining that his actions (albeit imperfect) were justified (in part by the true excellence of his oratory).

\section{Quintilian's Defense III: Cicero's Style as a Substitute for Character}

The final line of approach that Quintilian uses to support Cicero's goodness in 12.1 is a subtle shift in the discussion from an assessment of Cicero's character to an evaluation of his style. ${ }^{32}$ Quintilian freely intermingles moral and stylistic criticism throughout his work, most notably in his treatment of Seneca the Younger at the end of 10.1. ${ }^{33}$ In Cicero's case, the apparent discrepancy between the moral evaluation with which the defense begins and the stylistic one with which it ends makes more sense when understood as an attempt to distract the reader from Cicero's moral shortcomings. ${ }^{34}$ Quintilian's sleight-of-hand treats Cicero's stylistic excellence as a partial substitute for moral excellence, blending

32 The introduction of Jansen/Pieper/van der Velden (p. 313) in this volume discusses the distinct but related question of Cicero's "textualized voice [...] as a representation of Cicero himself, not only of his voice, but of the whole personality".

33 The interconnectedness of morals and stylistics is a prominent theme in Latin prose literature, the locus classicus being Sen. ep.114.1, talis hominibus fuit oratio qualis vita. See Berti 2018 ad loc. for bibliography, including a list of relevant passages in Cicero, especially Tusc. 5.47. On the mutual influence of "literary and moral criticism" in Quintilian's work cf. Winterbottom 1998, 327 and Dominik 1997. On Quintilian's imitation of Sen. ep.114 in Quint. 10.1.125-131, cf. Taoka 2011.

34 In calling Quintilian's shift of emphasis a distraction, I do not intend to suggest that Quintilian considers morality and stylistics to be two strictly separate fields. On the contrary, I think he would justify this section of his defense by appealing to their interrelation. 
the two realms in order to advance a stronger image of Cicero's overall excellence and support his status as a vir bonus (12.1.20):

\begin{abstract}
Quamquam enim stetisse ipsum in fastigio eloquentiae fateor, ac vix quid adici potuerit invenio, fortasse inventurus quid adhuc abscisurum putem fuisse (nam et fere sic docti iudicaverunt plurimum in eo virtutum, nonnihil fuisse vitiorum, et se ipse multa ex illa iuvenili abundantia coercuisse testatur): tamen, quando nec sapientis sibi nomen minime sui contemptor adseruit et melius dicere certe data longiore vita et tempore ad componendum securiore potuisset, non maligne crediderim defuisse ei summam illam ad quem nemo propius accessit.

For although I declare that Cicero stood upon the peak of eloquence, and that I can scarcely find anything able to be added [to his skill], I suppose perhaps I can find something still able to be snipped off (for the learned have usually judged that there was much excellence in him and minimal vice, and he himself attests that he curbed many things from his youthful abundance): nevertheless, since Cicero, not at all one to despise himself, did not affix to himself the name of sapiens, and since he certainly would have been able to speak better if he had been given a longer life and an era safer for composing, I would not be grudging to believe that he fell short of that height which no one has ever approached more closely.
\end{abstract}

In this passage Quintilian concedes small faults and then turns these faults entirely to Cicero's advantage. The "minimal vice" (nonnihil vitiorum) that learned people have detected in Cicero's style pales in comparison with his abundant excellences (plurimum virtutum). Furthermore, Cicero himself knew that he had a tendency towards overabundance and took steps to temper it, and if he had lived longer and in a more stable time he definitely (certe) would have written even better. It is true that Cicero was minime sui contemptor, but the fact that he never considered himself a sapiens and continued to look for the perfect orator without laying claim to the title shows considerable restraint, a moderation of character that corrects for his overabundance and his tendency to boast. Quintilian downplays Cicero's imperfections and repackages them as advantages that qualify Cicero for oratorical preeminence under Quintilian's moral definition.

\title{
5 Cicero, the Good Man, and the Guilty Man: Overlapping Defenses in $\mathbf{1 2 . 1}$
}

Quintilian's defense of Cicero in 12.1, while sophisticated in itself, is embedded within a still larger defense: that of Quintilian's definition of the orator as a vir bonus dicendi peritus. The defense of Cicero occurs within a series of four ob- 
jections that Quintilian answers in order to assert the validity of his definition. ${ }^{35}$ After satisfying these objections, Quintilian considers his point as proven (i.e., that the orator is a vir bonus) and begins the next phase of the discussion. ${ }^{36}$ The defense of Cicero's goodness cannot be separated from the wider rhetorical purpose of 12.1 and is motivated by it to a large extent.

Yet another purpose of the defense of Cicero is to give Quintilian an opportunity to illustrate one of the main lessons he is trying to teach in the Institutio's final book: namely, that the good orator is justified in defending a guilty client and that making such a defense does not compromise his fitness to be called a vir bonus dicendi peritus. ${ }^{37}$ Quintilian calls attention to his defense of Cicero qua defense, and he does so within a section of the text that aims to convince readers of a controversial point: the justifiability of defending the guilty. Quintilian's defense of Cicero can be read as a demonstration of how to perform such a difficult defense in practice.

Thus far in describing Quintilian's rehabilitation of Cicero, I have been using "defense" in a casual sense, but the text provides several indications that Quintilian wishes to flag this passage as a defense in a more formal way. After noting the conspiratio to discredit Cicero as a bad man (12.1.14), Quintilian foresees the hostility that may attend his answer and marks the importance of conciliating his audience (12.1.15: Magna responsi invidia subeunda est: mitigandae sunt prius aures). "Softening ears" is something that the orator must do to overcome prejudice in his audience, particularly the judge (e.g., 4.3.10: His igitur velut fomentis, si quid erit asperum, praemolliemus, quo facilius aures iudicum quae post dicturi erimus admittant). ${ }^{38}$ In 12.1, then, Quintilian is setting up a scenario with himself as the advocate, Cicero as the defendant, and his readers as the judges. He will answer the charges of the conspiratio and defend Cicero in a way compatible with his promotion of the vir bonus dicendi peritus. ${ }^{39}$ Quintilian first attributes to Cicero the voluntas of a civis optimus, already an important compromise insofar as he is proving that Cicero had good intentions, not that he was perfect

35 Quintilian envisions objections in Quint. 12.1.10; 12.1.14; 12.1.23; and 12.1.33 that he refutes severally.

36 Although the standard divisions of the text may differ from what Quintilian himself recognized, I think it is permissible to treat Quint. 12.1 as a unit based on the first sentence of 12.2, which takes for granted the point that 12.1 argued for (quando igitur orator est vir bonus).

37 Cf. Quint. 12.1.44: Non enim hoc agimus, ut istud illi quem formamus viro saepe sit faciendum, sed $u$, si talis coegerit ratio, sit tamen vera finitio oratorem esse virum bonum dicendi peritum. 38 By mentioning the aures he must soften, Quintilian is speaking metaphorically, unless we think he intends his work to be read aloud.

39 Of course, Demosthenes is also a defendant in this case, but I focus on Cicero because Quintilian defends him at greater length and with more at stake. 
in every one of his actions. Then he offers as evidence (testimonium) Cicero's noble deeds (his consulship, his provincial administration, his refusal to join Caesar's land commission, etc.). Testimonium, of course, can have the technical meaning of "evidence" in the context of a trial (e.g., 5.7.1; 4; 5). Quintilian both displays Cicero's actions as testimonia and uses Cicero himself as a witness in the portion of the defense dealing with style (12.1.20: et se ipse [sc. Cicero] multa ex illa iuvenili abundantia coercuisse testatur). The presentation of evidence following a bid for a receptive hearing signals that readers should attend to this passage as a working example of defense.

The importance of this passage within the larger arc of 12.1 becomes clearer as Quintilian examines the orator's prerogative to defend the guilty for a good reason (12.1.33-45). This discussion requires, in the first place, a defense of his own moral uprightness. In 12.1.33 Quintilian confronts a line of thinking that tries to contrast rhetoric's colores with the alliance of goodness and truth.

Videor mihi audire quosdam (neque enim deerunt umquam qui diserti esse quam boni malint) illa dicentis: "Quid ergo tantum est artis in eloquentia? Cur tu de coloribus et difficilium causarum defensione, nonnihil etiam de confessione locutus es, nisi aliquando vis ac facultas dicendi expugnat ipsam veritatem? Bonus enim vir non agit nisi bonas causas, eas porro etiam sine doctrina satis per se tuetur veritas ipsa”.

I seem to hear certain people (for those who would prefer to be clever at speaking rather than good will never be lacking) saying things like this: "Why then is there so much artfulness in eloquence? Why did you speak about 'colors' and defense of difficult cases and even about confession, unless sometimes force and capability at speaking overcome truth itself? The good man does not plead any cases except good ones, and besides, the truth itself protects good cases even without learning”.

Quintilian's own project and the integrity of the vir bonus it proposes are at risk from this objection, which he deals with at once: "When I respond to these people first about my own work, I will also meet the objection about the duty of the good man, if sometimes reason leads him to a defense of guilty people" (12.1.34). ${ }^{40}$ Multiple levels of defense are at work here. When Quintilian argues that the officium of the good man may involve occasionally defending a guilty person, he also has to defend his own ethos for supporting this position. In addition to praising the educational benefits of argument in utramque partem (12.1.34-35), Quintilian insists that the good orator with upright motives is sometimes entitled to distract the judge from the truth (12.1.36):

40 Quint. 12.1.34: Quibus ego, cum de meo primum opere respondero, etiam pro boni viri officio, si quando eum ad defensionem nocentium ratio duxerit, satisfaciam. 
Verum et illud, quod prima propositione durum videtur, potest adferre ratio, ut vir bonus in defensione causae velit auferre aliquando iudici veritatem. Quod si quis a me proponi mirabitur (quamquam non est haec mea proprie sententia, sed eorum quos gravissimos sapientiae magistros aetas vetus credidit), sic iudicet, pleraque esse quae non tam factis quam causis eorum vel honesta fiant vel turpia.

But reason is also able to assert what at first proposition seems harsh, that a good man in the defense of a cause may wish sometimes to mislead the judge. And if anyone marvels that I am proposing this (although this opinion does not belong to me but to those whom an earlier age believed to be teachers of wisdom), let that person judge that a great many things become upright or shameful not so much because of the deeds themselves as because of their motives.

Shortly after mentioning the vir bonus' right to mislead the judge (auferre aliquando iudici veritatem), Quintilian casts the doubtful reader as iudex (si quis [...] mirabitur [...] sic iudicet), thus setting up a framework with himself as advocate and vir bonus pleading a difficult case before the reader as iudex. This playful setup lets the reader observe Quintilian as he performs an upright defense of a difficult case and illustrates the principle he is trying to teach. It also disposes the reader-iudex to reach a favorable judgment of Quintilian's position (i.e., that it is permissible to defend the guilty in certain circumstances). Quintilian is not trying to undermine the importance of truth altogether, but he does want to relax the bond between truth and goodness in order to make room for the good that he believes can accrue from defending the guilty, an enterprise that often demands deception.

In 12.1.40 - 44, Quintilian lists a number of situations in which the vir bonus would have a worthy reason to use rhetoric deceptively in order to ensure a just outcome (e.g., defending a would-be tyrant-killer in the tyrant's court). Two of these situations are especially useful for framing Quintilian's defense of Cicero as a teaching example of a difficult defense. First, a guilty person who is accused truthfully may become a good man in the future, and the orator will want to preserve this potential by defending him. ${ }^{41}$ In 12.1.20 Quintilian had posited that if Cicero had lived a longer life, he might have tempered his stylistic abundance and advanced even further towards perfection (fortasse inventurus quid adhuc abscisurum putem fuisse, melius dicere certe data longiore vita et tempore ad componendum securiore potuisset). Cicero's own diagnosis of his stylistic faults and his actions in response to them show, according to Quintilian, that he is aware of

41 Quint. 12.1.42-43: Ad hoc nemo dubitabit quin, si nocentes mutari in bonam mentem aliquo modo possint, sicut posse conceditur, salvos esse eos magis re publica sit quam puniri. Si liqueat igitur oratori futurum bonum virum cui vera obicientur, non id aget ut salvus sit? 
his tendencies towards excess and is willing to correct himself (se ipse multa ex illa iuvenili abundantia coercuisse testatur). ${ }^{42}$ Quintilian portrays Cicero as wellintentioned, theoretically capable of progress (even though he is dead), and thus worth rehabilitating.

Second, in 12.1.43 Quintilian mentions a situation in which a good man can support a bad man in order to secure the common good.

Da nunc ut crimine manifesto prematur dux bonus et sine quo vincere hostem civitas non possit: nonne ei communis utilitas oratorem advocabit? Certe Fabricius Cornelium Rufinum, et alioqui malum civem et sibi inimicum, tamen, quia utilem sciebat ducem, imminente bello palam consulem suffragio suo fecit, atque id mirantibus quibusdam respondit, a cive se spoliari malle quam ab hoste venire. Ita hic si fuisset orator, non defendisset eundem Rufinum vel manifesti peculatus reum?

Grant now that a good leader is being pressured by a clearly true accusation, and that without him the city cannot conquer the enemy: will not the common utility summon the orator to his defense? Certainly Fabricius, although Cornelius Rufinus was otherwise a wicked citizen and a personal enemy to him, nevertheless, because he knew him to be a useful leader when war threatened, openly made him consul by his own vote, and to those wondering at his behavior he responded that he preferred to be despoiled by a fellow citizen than to be sold into slavery by the enemy. Therefore, if Fabricius had been an orator, would he not have defended that same Rufinus even if the latter were standing trial for obvious embezzlement?

Although Quintilian's defense of Cicero is framed in much milder terms, ${ }^{43}$ the discussion of Fabricius and Rufinus is relevant to the situation Quintilian finds himself in. The point of the comparison is not to suggest that Quintilian thinks Cicero is actually a bad man but rather to highlight a common motivation between the defense of Cicero and the defense of Rufinus: namely, the preservation of the defendant's usefulness for a larger good that meets a pressing need of society. In the case of Cicero, this larger good is his usefulness for Quintilian's enterprise of educating the vir bonus dicendi peritus, an enterprise whose urgency arises (at least in part) from the depravity of informer culture under the Flavians. $^{44}$

By its placement in 12.1, Quintilian's defense of Cicero anticipates and illustrates his theoretical approach to the question of whether the orator can defend a guilty client and still retain his moral status. A dizzying array of defenses atop defenses comes into view. Quintilian, styling himself a vir bonus, defends Cice-

42 Cf. Cic. orat. 107.

43 Cicero is far from being a malus civis like Rufinus; on the contrary, he has the voluntas of a civis optimus.

44 Cf. Winterbottom 1964, $90-97$. 
ro's (contested) status as a vir bonus in order to uphold his definition of the orator as a vir bonus dicendi peritus. Since the duties of this vir bonus dicendi peritus include defending the guilty in order to achieve a good outcome, Quintilian uses the defense of Cicero to demonstrate this challenging task for his readers. ${ }^{45}$

\section{Cicero, Quintilian, and the Quest for the Perfect Orator}

As Quintilian defends Cicero, he posits a subtle but persistent identification between himself and Cicero that marks the uniqueness of his own authorial project within the tradition of Ciceronian reception.

In 12.10.12-13, championing Cicero's rightful place as artistic paragon (in omnibus quae in quoque laudantur eminentissimum), Quintilian recalls the vehemence with which Cicero's critics attacked him after his death. After his proscription and murder, a multitude of haters, enviers, and flatterers attacked the dead Cicero, who was no longer able to defend himself (non responsurum invaserunt). ${ }^{46}$ Quintilian, however, does offer a response to Cicero's attackers: first, by allowing Cicero himself to respond (12.1.17: quibus optime respondit ipse) and second, by speaking on his behalf in all the various defenses and mini-defenses that arise in the Institutio. Quintilian even takes on Cicero's persona for a brief moment. Recall that Quintilian had framed the problem of 12.1.14 as a conspiratio against his own moral vision of the orator (12.1.14: Nunc de iis dicendum est quae mihi quasi conspiratione quadam vulgi reclamari videntur). The use of conspiratio evokes one of the most outstanding events of Cicero's career: Catiline's conspiracy. ${ }^{47}$ While Catiline's conspiracy had attempted to oust Cicero from

45 The complex circularity of these levels of defense serves, I think, to urge the reader to reread, wrestle, and play with the material (cf. Dozier 2014, 85-86, though I disagree with his dismissal of the vir bonus dicendi peritus as "a patently artificial ideal”, and Taoka 2011, 135).

46 Quint. 12.10.13: Postea vero quam triumvirali proscriptione consumptus est, passim qui oderant, qui invidebant, qui aemulabantur, adulatores etiam praesentis potentiae non responsurum invaserunt.

47 As Robert Kaster pointed out to me, Cicero himself is much more likely to use coniuratio rather than conspiratio to describe what English-speakers mean by "conspiracy". When he uses conspiratio, it is sometimes in a positive sense ("harmony", e.g., Cic. dom. 28, Cat. 4.22), sometimes in a negative sense ("conspiracy", e.g., Cic. Scaur. 20; 37 and Deiot. 11). Similarly, Quintilian uses coniuratio to speak of the Catilinarian conspiracy in Quint. 11.1.18 and 11.1.23, but all four of his uses of conspiratio are negative and he treats it as a synonym for coniuratio (e.g., Quint. 12.7.2: Quare neque sociorum querelas nec amici vel propinqui necem nec erupturas in rem publicam conspirationes inultas patietur orator). 
the consulship, the conspiratio in 12.1.14 tries to invalidate Quintilian's definition of the orator by undermining Cicero's moral integrity. By doing away with Quintilian's chief exemplar, it is a double attack on Cicero and Quintilian. As he demolishes the objections of this conspiratio, Quintilian reenacts Cicero's suppression of Catiline's attempt to overthrow his consulship and preserves both Cicero's authority and his own. Quintilian thus aims to satisfy critics of his definition, portray Cicero in a positive light, and establish himself in the Ciceronian role of suppressing a harmful conspiracy for a noble purpose.

Quintilian also seems keen to take on a Ciceronian role in the enterprise of writing rhetorical theory. In 12.1.18-19, Quintilian turns his admission that Cicero was not (technically speaking) a perfect orator into a proclamation of his faithfulness to Cicero and his extension of Cicero's theoretical project.

Ego tamen secundum communem loquendi consuetudinem saepe dixi dicamque perfectum oratorem esse Ciceronem, ut amicos et bonos viros et prudentissimos dicimus vulgo, quorum nihil nisi perfecte sapienti datur: sed cum proprie et ad legem ipsam veritatis loquendum erit, eum quaeram oratorem quem et ille quaerebat.

Nevertheless, according to common usage in speaking, I have often said and will say again that Cicero is a perfect orator, in the same way that we commonly say that our friends are good men and exceedingly wise, titles which are not granted except to the perfectly wise man. But when it is necessary to speak properly and in accordance with the very law of truth, I will seek that orator whom even Cicero himself was seeking.

Quintilian here pledges to carry forward Cicero's avowed aim of searching for the ideal orator. ${ }^{48}$ This stance enables him both to continue Cicero's project and to transform it. ${ }^{49}$ Cicero's perfect orator is supposed to be a Platonic ideal apprehensible by thought and mind. ${ }^{50}$ Quintilian, by contrast, insists that the perfect orator may someday exist and makes it his mission to help bring him into being. ${ }^{51}$ In this way, Quintilian at once affirms Cicero's project, continuing his

48 Austin 1948 ad loc. links this passage with Cic. orat. 7: Atque ego in summo oratore fingendo talem informabo qualis fortasse nemo fuit. Non enim quaero quis fuerit, sed quid sit illud, quo nihil esse possit praestantius, quod in perpetuitate dicendi non saepe atque haud scio an numquam, in aliqua autem parte eluceat aliquando, idem apud alios densius, apud alios fortasse rarius. Latin text of the Orator is from A.S. Wilkins' 1903 OCT.

49 Cf. Logie 2003, 368-373 for Quintilian's belief that he is an original author in his own right. 50 Cic. orat. 8: Quod neque oculis neque auribus neque ullo sensu percipi potest, cogitatione tantum et mente complectimur.

51 See for instance Quint. 12.1.25 and 12.1.31: Nam si natura non prohibet et esse virum bonum et esse dicendi peritum, cur non aliquis etiam unus utrumque consequi posset? Cur autem non se quisque speret fore illum aliquem? 
quest and transmitting Cicero's textual, personal, and philosophical legacy, and incorporates Cicero into an enterprise very much his own. ${ }^{52}$

It is in light of Quintilian's simultaneous identification with Cicero and selfdifferentiation from him that the prologue of Book 12 needs to be read. As Quintilian's young orator finishes his training in the schools of the rhetor and prepares to navigate for himself, Quintilian, claiming to feel overwhelmed by the immensity of the task he has undertaken, introduces an extended nautical image (12.3-4):

Nunc "caelum undique et undique pontus". Unum modo in illa immensa vastitate cernere videmur M. Tullium, qui tamen ipse, quamvis tanta atque ita instructa nave hoc mare ingressus, contrahit vela inhibetque remos et de ipso demum genere dicendi quo sit usurus perfectus orator satis habet dicere. At nostra temeritas etiam mores ei conabitur dare et adsignabit officia.

Now "sky on all sides and on all sides the swell". Only one person do I seem to pick out in that boundless waste, Marcus Tullius, and even he himself, although he has entered upon this sea with such a great and well-outfitted ship, draws in his sails and restrains his oars and considers it sufficient to discuss only that style of speaking which the perfect orator will use. But my own rashness will try to give the orator principles of character as well and will assign him duties.

Quintilian uses nautical imagery to illustrate his own authorial role vis-à-vis the accomplishments of other authors, and especially of Cicero. ${ }^{53}$ The vast expanse of sea represents the panorama of oratorical achievement open to the rhetorical theorist. Most writers of rhetorical manuals hug the shore (12.2) and in the more technical parts of his treatise Quintilian's was one more boat in their midst. ${ }^{54}$ Numbers thin as the subject matter shifts to the ratio eloquendi and Quintilian realizes that he is one of the first to venture so far from port. It is at this point

52 Cf. Dugan 2005, 332 (cited below) for Quintilian's transmission of the Ciceronian legacy. For a summary of the general scholarly sense that Quintilian lacked originality and a compelling argument in defense of Quintilian's “aspirations toward an originary and proprietary authorship”, cf. Logie 2003, 371. Along these lines, Winterbottom 1964 writes that "it is clear that Quintilian realized that he was innovating” (90), while Kennedy 1969 downplays Quintilian’s originality but still admits that "no Roman writer puts quite so much emphasis on the moral character of the orator” as Quintilian (123).

53 Ibid. (Kennedy). Curtius 1953, 128-129 gives a neat (though not exhaustive) catalogue of nautical imagery that serves a programmatic purpose in Latin poetry and prose. In addition to Vergil, Horace, Ovid, Propertius, and Statius, he mentions Cic. Tusc.4.5.9 and the Quintilian passage we are examining here (129). For the Greek roots of nautical imagery in lyric poetry (within a larger discussion of Horace), cf. Cucchiarelli 2015.

54 Quint. 12. pr. 2-3. 
that Quintilian envisions Cicero's boat, stark against the watery waste. Cicero has advanced far into open sea where no others have sailed before, and to a great degree he has established the trajectory of the ideal-oratorical project. But Cicero stops short (contrahit vela inhibetque remos), discussing only the style of the perfect orator (de ipso demum genere dicendi quo sit usurus perfectus orator). ${ }^{55}$ Quintilian is the one who will press onwards, beyond Cicero, to outline the orator's moral characteristics and responsibilities. In this stretch of sea Quintilian has no antecedens and must establish his own course (12.3).

This passage is emblematic both of Quintilian's veneration for Cicero and of his own authorial self-fashioning in the Ciceronian tradition. In both the defense of Cicero in 12.1 and in the nautical prologue of Institutio 12, Cicero is part of a project that is distinctively Quintilian's: the making of the vir bonus dicendi peritus. At the same time, Quintilian's project is uniquely shaped by Cicero's concerns and imprinted with his image. ${ }^{56}$ Sailing beyond Cicero on a course that Cicero himself established is Quintilian's way of signaling his authorial expansion upon Cicero's legacy. ${ }^{57}$ In so doing, he pays the ultimate tribute to the Ciceronian legacy as a dynamic, ever-evolving enterprise, the paradox of which is that the very act of surpassing Cicero is quintessentially Ciceronian.

55 Quintilian is referring to Cicero's Orator, which emphasizes the genera dicendi that the ideal orator will have mastered (e.g., $100-101)$.

56 As Dugan 2005 explains, Quintilian's portrayal of Cicero as an oratorical exemplar "fulfills the terms in which Cicero first conceived of his program of self-fashioning in the Pro Archia: an image of himself that would abide within Roman cultural memory and transmit his legacy far into posterity" (332).

57 Cf. Logie 2003, 369. 
